\title{
Biological Activity of Phenothiazine Sulfonamides
}

\author{
Boggavarapu Jyothia, Suryadevara Kalpanab, Nannapaneni Madhavi
}

\begin{abstract}
Background: Antibacterial activities in "dimethylsulfoxide (DMSO)" were executed by the broth dilution method utilizing nutrient agar. By using the agar cup bioassay method antifungal activities were calculated with "Clotrimazole" as the standard. The novel compounds 1a-j have been evaluated in vitro for their antibacterial activity by "Gram-positive bacteria namely Bacillus subtilis, Bacillus sphaericus and Staphylococcus aureus and three Gram-negative bacteria Pseudomonas aeruginosa", "Klebsiella aerogenes and Chromobacterium violaceum". All ten compounds were analysed for their antifungal activity against five test "organisms Aspergillus niger, Chrysosporium tropicum, Rhizopus oryzae, Fusarium moniliforme and Curvularia lunata". Among the isolated compounds $1 \mathrm{~d}$ and 1e evinced dynamic Movement towards both gram certain What's more gram negative microscopic organisms. Mixes Id Also If uncovered useful antifungal action. All the secluded compounds were scrutinized for their antibacterial and antifungal activities and most of the compounds manifested remarkable anti bacterial and anti fungal activity.
\end{abstract}

Keywords: phenothiazine, sulfonamide, antibacterial, antifungal activity.

\section{INTRODUCTION}

Phenothiazine was first devised by Bernthsen in 1883, resembles the methylene blue in structure and which plays an significant role in dye chemistry [1]. Chlorpromazine (CPZ) shows distinct antimicrobial properties. Phenothiazine shows insecticidal, urinary antiseptic, anti-helmintic [2] properties. Its derivatives also exhibit special emphasis in human medicine as antihistamines [3-5], as antiemetic [7] ,neuroleptic ,antipsychotic, tranquilizer , antioxidants [8], multidrug reversal agents $[9,10]$ and helps in the therapy of Parkinson's disease [6].

Due to the increased importance of heterocyclic compounds many attempts were done to synthesize phenothiazines. It decreases cell division and thus work in cancer therapy.

Sulfonamides exhibit potent therapeutic activities [11] such as antifungal, nephrotoxic, analgesic, antibacterial[12], protease inhibitory activity, antioxidant, anticarbonic anhydrase [13,14], antitumour, alopecia, diuretic[15], hypoglycemic, antithyroid, antiinflammatory[16,17], antiglaucoma, anticonvulsant, antiviral, antineoplastic, etc[18]. Sulfonamide derivatives were extensively used because these are less expensive. These

Revised Manuscript Received on July 22, 2019.

Boggavarapu Jyothia, Department of Chemistry, Swarna Bharathi institute of science and technology,Khammam,Telangana,India.

Suryadevara Kalpan, Department of chemistry, SDMSM Kalasala, Vijayawada.

Nannapaneni Madhavi, PG Department of Chemistry, J.K.C College, Guntur, Andhra Pradesh, India Email: madhavijkcchempg@gmail.com drugs are explored as chemotherapeutic agents. Its potent antimicrobial activity is due to the replacement of hydrogens of sulfonamide with withdrawing heteroaromatic ring groups. It plays an essential role in platelet comprehensive association and adherence. It shows its antibacterial activity by inhibiting PABA synthesis in bacterial cells. To enhance biological activity phenothiazines and sulfonamides are integrated with each other.

\section{EXPERIMENTAL}

All the chemicals used in this analysis were of Analytical Grade (AR) with the highest level of purity and were used without further purification. All the analyzed compounds1a-j were purged by column chromatography by employing silica gel as stationary phase.
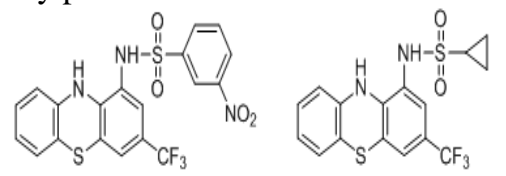

$1 a$

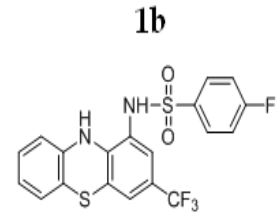

$1 c$

1d<smiles>CS(=O)(=O)Nc1cc(C(F)(F)F)cc2c1Nc1ccccc1S2</smiles><smiles>Cc1ccc(S(=O)(=O)Nc2cc(C(F)(F)F)cc3c2Nc2ccccc2S3)cc1</smiles>

1e

1f

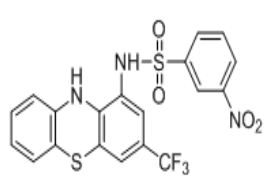

$1 g$

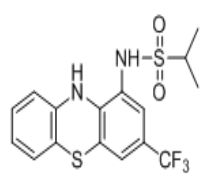

1h<smiles>C=CS(=O)(=O)Nc1cc(C(F)(F)F)cc2c1Nc1ccccc1S2</smiles>

1j 


\section{RESULTS AND DISCUSSION:}

A. Antibacterial activity:

At $100 \mu \mathrm{g} / \mathrm{ml}$ concentration in vitro screening of antibacterial activities of 1a-j in dimethylsulfoxide (DMSO) were released by the soup weakening strategy utilizing supplement agar next to "Gram-negative microbes Pseudomonas aeruginosa", "Klebsiella aerogenes", "Chromobacterium violaceum and Gram-positive microscopic organisms Bacillus subtilis". "Bacillus sphaericus and Staphylococcus aureu"s. Inhibitory is determined by MIC which was measured by the broth dilution method [19]. The instant supplement stock medium (HiMedia, 25g) was dangled in refined water $(100 \mathrm{ml})$ and warmed until it is crumbled totally. The medium and test cylinders were autoclaved at a weight of $15 \mathrm{lb} / \mathrm{inc} 2$ for 25 minutes. A gaggle of disinfected test tubes with supplement juices medium was topped with cotton plugs. The test compound is broken up in dimethylsulfoxide (DMSO) at a centralization of $100 \mu \mathrm{g} / \mathrm{ml}$ and added to the main test tube, which is sequentially weakened. A fixed $0.5 \mathrm{ml}$ volume of medium-term culture is intercalary to all the test cylinders and after that hatched at $35^{\circ} \mathrm{C}$ for $24 \mathrm{~h}$. After $24 \mathrm{~h}$, these cylinders were pondered for darkness. Ciprofloxacin was utilized as a standard for correlation. Results are given in Table 1.

Table 1. Antibacterial activity data of compounds $1 a-j$

\begin{tabular}{|c|c|c|c|c|c|c|}
\hline \multirow{3}{*}{$\begin{array}{l}\text { Comp } \\
\text { ound }\end{array}$} & \multicolumn{6}{|c|}{$\mathrm{MIC}^{\mathrm{a}, \mathrm{b}}$} \\
\hline & \multicolumn{3}{|c|}{ Gram-positive } & \multicolumn{3}{|c|}{ Gram-negative } \\
\hline & $\begin{array}{l}\text { B.su } \\
\text { bstilis }\end{array}$ & $\begin{array}{l}\text { B.sp } \\
\text { haer } \\
\text { ius }\end{array}$ & $\begin{array}{l}\text { S.au } \\
\text { reus }\end{array}$ & $\begin{array}{l}\text { P.aeru } \\
\text { ginosa }\end{array}$ & $\begin{array}{l}\text { K.ae } \\
\text { roge } \\
\text { nes }\end{array}$ & $\begin{array}{l}\text { C.vi } \\
o l \\
\text { aceu } \\
m\end{array}$ \\
\hline $1 \mathbf{a}$ & 22 & 24 & 24 & 32 & 24 & 30 \\
\hline $1 b$ & 21 & 24 & 21 & 28 & 25 & 26 \\
\hline 1c & 24 & 25 & 30 & 35 & 26 & 28 \\
\hline 1d & 18 & 21 & 18 & 31 & 23 & 25 \\
\hline $1 \mathrm{e}$ & 18 & 21 & 20 & 27 & 24 & 23 \\
\hline 1f & 20 & 22 & 18 & 27 & 22 & 25 \\
\hline $1 \mathrm{~g}$ & 23 & 27 & 20 & 37 & 26 & 25 \\
\hline $1 \mathrm{~h}$ & 21 & 25 & 24 & 31 & 24 & 22 \\
\hline $\mathbf{1 i}$ & 21 & 21 & 17 & 30 & 23 & 26 \\
\hline $\mathbf{1 j}$ & 23 & 24 & 25 & 27 & 24 & 24 \\
\hline $\begin{array}{l}\text { Ciprofl } \\
\text { pxacin }\end{array}$ & 20 & 25 & 20 & 30 & 25 & 25 \\
\hline
\end{tabular}

The aftereffects of antibacterial screening stipulated that mixes $1 \mathrm{a}-\mathrm{j}$ arranged great action. The mixes $1 \mathrm{~d}$ and $1 \mathrm{f}$ having fluoro and methyl bunches as substituents on the benzene ring displayed a superior movement. The activity of compound depends upon the nature and position of the substituent at the phenyl group. The presence of substituents especially nitro, fluoro and methyl groups when attached to phenyl ring increases the activity remarkably. Compounds $\mathbf{1 d}$ and $\mathbf{1 f}$ exhibited promising activity. Introduction of nitro group at aryl moiety decreases the activity of the compounds. The most active compound of the series was $\mathbf{1 d}$, which exhibited activity comparable to that of Ciprofloxacin. Nonetheless, the level of hindrance differed both with test compound just as with the microbes utilized in the present examination. All in all, practically all the arrangement of mixes $1 \mathrm{a}-\mathrm{j}$ revealed great movement by impeding development of the considerable number of microorganisms to a more prominent degree. These amazing results may be due to the existence of the phenothiazine ring linked to sulfonamide group.

\section{B. Antifungal activity:}

Antifungal exercises for 1a-j were impeled Eventually Tom's perusing utilizing that agar glass bioassay technique [20] with Clotrimazole as the standard. Those exacerbates were inspected for their antifungal movement against five test organisms, "Aspergillus niger, Chrysosporium tropicum, Rhizopus oryzae, Fusarium moniliforme and Curvularia lunata" operated at $100 \mu \mathrm{g} / \mathrm{ml}$ concentration. The moment supplement stock medium (HiMedia, 40g) was suspended in refined water $(1000 \mathrm{ml})$ and warmed until it is deteriorated completely. The medium and petri dishes were autoclaved at a weight of $15 \mathrm{lb} / \mathrm{inc} 2$ for 20 minutes and furthermore the medium was gushed into sterile petri dishes underneath sterile conditions during a streamline stream chamber. When the medium in the plates was hardened, $0.5 \mathrm{ml}$ of culture of the test animal was vaccinated and purposely fringe spread over the agar surface with a sterile L-shaped bar. Arrangements were prepared by solvating plant extricate in dimethylsulfoxide (DMSO) at a convergence of $100 \mu \mathrm{g} / \mathrm{ml}$. Agar inoculation cups were scooped out with a $6 \mathrm{~mm}$ sterile plug borer and moreover the fronts of the dishes were restored. To each cup, $100 \mu \mathrm{g} / \mathrm{ml}$ of the test course of action was incorporated. Controls were continued with DMSO and Clotrimazole $(100 \mu \mathrm{g} / \mathrm{ml})$. The treated and controls were put at room temperature for 72-95h. Restriction zones were settled and separation crosswise over was resolved in millimeter. Three to four repeats were continued for each treatment. The results are given in Table-2.

Table 2. Antifungal activity screening data of compounds $1 a-j$

\begin{tabular}{|c|c|c|c|c|c|}
\hline \multirow[b]{2}{*}{$\begin{array}{l}\text { Comp } \\
\text { ound }\end{array}$} & \multirow[b]{2}{*}{$\begin{array}{c}N i g \\
e r\end{array}$} & \multirow[b]{2}{*}{$\begin{array}{c}C . \\
\text { tropicu } \\
m \\
\end{array}$} & \multicolumn{3}{|c|}{ Zone of inhibition ${ }^{a, b}$} \\
\hline & & & $\begin{array}{c}R . \\
\text { oryzae }\end{array}$ & $\begin{array}{c}F . \\
\text { monilifo } \\
\text { rmae }\end{array}$ & $\begin{array}{c}C . \\
\text { lunata }\end{array}$ \\
\hline $1 \mathrm{a}$ & 24 & 25 & 18 & 19 & 20 \\
\hline $1 b$ & 23 & 28 & 14 & 17 & 23 \\
\hline $1 c$ & 27 & 24 & 21 & 18 & 25 \\
\hline 1d & 29 & 29 & 23 & 21 & 27 \\
\hline $1 \mathrm{e}$ & 28 & 26 & 21 & 19 & 20 \\
\hline 1f & 30 & 28 & 24 & 19 & 29 \\
\hline $1 \mathrm{~g}$ & 24 & 22 & 17 & 14 & 18 \\
\hline $1 \mathrm{~h}$ & 23 & 25 & 14 & 17 & 22 \\
\hline $1 \mathbf{i}$ & 26 & 21 & 21 & 19 & 21 \\
\hline $\mathbf{1 j}$ & 24 & 25 & 22 & 19 & 25 \\
\hline $\begin{array}{c}\text { Clotrim } \\
\text { azole }\end{array}$ & 30 & 29 & 23 & 20 & 28 \\
\hline
\end{tabular}

${ }^{b}$ Concentration $100 \mu \mathrm{g} / \mathrm{ml}$ ".

The antifungal movement results revealed that mixes $1 \mathrm{a}-\mathrm{j}$ were outstandingly deadly towards each of the five parasites and they were deadly even at $100 \mu \mathrm{g} / \mathrm{ml}$ fixation. In the arrangement 1 , mixes $1 \mathrm{~d}$ and $1 \mathrm{f}$ demonstrated high antifungal movement which might be because of the nearness of fluoro, methyl bunches as substituents on the benzene ring. The antifungal movement of these mixes analogized with the quality medication Clotrimazole, which swore that they have promising action. Taking everything into account, practically all the arrangement of mixes $1 \mathrm{a}-\mathrm{j}$ were modestly cyanogenic towards Those developments under assessment What's more they were disappointment Indeed during $100 \mu \mathrm{g} / \mathrm{ml}$ fixation in examination for standard Clotrimazole In steady focus. This 
might be suitable to the presence of phenothiazine ring joined to sulfonamide group.

\section{IV.CONCLUSION}

The compounds showed diverge actions next to cultured bacterial and fungal strain. The compounds 1d and 1f were exhibited significant antibacterial activity against B.substilis gram (+) ve bacteria and P.aeruginosa gram (-) ve bacteria. Some derivatives were less effective with standard Ciprofloxacin. It was exigent to note that standard antifungal drug Clotrimazole displayed less activity against A.niger and effective with F.moniliformae with 1d and 1f. So synthetic analogues which possess higher activities should be suggested for further preclinical screening which could be useful in withstanding the bacterial and fungal infections.

\section{ACKNOWLEDGEMENTS:}

The authors were thankful to management, J.K.C. College, Guntur for providing laboratory facilities.

\section{REFERENCES}

1. Venkataraman, k. "The chemistruofsynthetic dyes", Vol. II, pp. 791. Academic Press, inc., Newyork 1952.

2. Findlagy,G. M.: "Recent advances in Chemotherapy", 3rd edition, vol. I, pp. 124. Theblakiston Company, Philadelphia, 1950.

3. Halpern, B. N.: "Compt. Rend. Soc. Biol”. 140, 363, 1946.

4. Halpern, B. K., and Ducrot, R.: Compt. Rend. Soc. Biol. 140, 1946, pp 361 .

5. Vanderbrook, M. J., Olson, k. J., Richmon\&di, R., and Iuizenema, H. J. Pharmacol. Exptl. Therap. 1948, 94, $19 \mathrm{i}$.

6. Burger, A.: Medicinal chemistry, vol. I, 1951, pp. 456. Interscience Publishers, inc., NewYork .

7. Friend, D. G., and Cummins, j. f.: J. Am. Med. Assoc. 163 1953,pp481.

8. Murphy, C. M.,Rainer, H., and Smith, N. L.: Anal. Chem. 42, 1950, pp2479.

9. (a) Schmidt, M.; Teitge, M.; Castillo M. E.; Brandt, T.; Dobner. B.; Langner, A. Arch. Pharm. (Weinheim) 2008, 341, pp 624. (b) Bissi, A.; Meli, M.; Gobbi, S.; Rampa, A.; Tolomeo, M.; Dusonchet, L. Bioorg. Med. Chem., 16, 2008, pp 6474.

10. Gabriela P. Sarmiento,a Graciela Y. Moltrasio,a and Albertina G. Moglionib*"An alternative synthetic route to the neuroleptic compound Pipothiazine". ARKIVOC (vii), 2009, pp33-41.

11. A. Alsughayer, A.Z.A. Elassar, S. Mustafa, F. Al Sagheer, "Synthesis, structure analysis and antibacterial activity of new potent sulfonamide derivatives."J. Biomater. Nanobiotechnol. 2, 2011,pp143.

12. F. Zani, P. Vicini, "Antimicrobial activity of some 1, 2-benzisothiazoles having a benzenesulfonamide moiety." Arch. Pharm. 331, 1998, pp 219-223.

13. Ö. Güzel, A. Innocenti, A. Scozzafava, A. Salman, C.T. Supuran, Carbonic anhydrase inhibitors. "Phenacetyl-, pyridylacetyl-and thienylacetyl-substituted aromatic sulfonamides act as potent and selective isoform VII inhibitors". Bioorg. Med. Chem. Lett. 19, 2009, pp 3170-3173.

14. Scozzafava, T. Owa, A. Mastrolorenzo, C.T. Supuran, "Anticancer and antiviral sulfonamides". Curr. Med. Chem. 10, 2003, pp 925-953.

15. T.H. Maren, "Relations between structure and biological activity of sulfonamides". Annu. Rev. Pharmacol. Toxicol. 16, 1976, pp 309-327.

16. N.S. El-Sayed, E.R. El-Bendary, S.M. El-Ashry, M.M. El-Kerdawy, "Synthesis and antitumor activity of new sulfonamide derivatives of thiadiazolo [3, 2-a] pyrimidines". Eur. J. Med. Chem. 46, 2011,pp 3714-3720.

17. A.K. Tiwari, A.K. Mishra, A. Bajpai, P. Mishra, R.K. Sharma, V.K. Pandey, V.K. Singh, "Synthesis and pharmacological study of novel pyrido-quinazolone analogues as anti-fungal, antibacterial, and anticancer agents". Bioorg. Med. Chem. Lett. 16, 2006, pp $4581-4585$.
18. S. Yotphan, L. Sumunnee, D. Beukeaw, C. Buathongjan, V. Reutrakul, "Iodine-catalyzed expeditious synthesis of sulfonamides from sulfonyl hydrazides and amines". Org. Biomol.Chem. 14, 2016, pp 590-597.

19. National Committee for clinical Laboratorystandards(NCCLS)standard for dilution antimicrobial susceptibility tests for bacteria, which grows aerobically; Nat.Comm.clini Lab stands, Ltd, Villanova, 1982, pp242-286.

20. E. Margery Linday, "Practical Introduction to Microbiology E. \& F.N. Spon Ltd.” London, 1962, pp 177. 